Our Nature (2011) 9: 73-82

\title{
Biomass and Net Primary Productivity in three different Aged Butea Forest Ecosystems in Western India, Rajasthan
}

\author{
J.I. Nirmal Kumar ${ }^{1 *}$, P.R. Sajish ${ }^{1}$, R.N. Kumar ${ }^{2}$ and K. Patel ${ }^{1}$ \\ ${ }^{1}$ P.G. Department of Environmental Science and Technology, Institute of Science and Technology for Advanced \\ Studies and Research (ISTAR), Vallabh Vidya Nagar, Anand, Gujarat- 388 120, India. \\ ${ }^{2}$ Department of Bioscience and Environmental Science, N.V. Patel College of Pure and Applied Sciences, \\ Vallabh Vidyanagar - 388 120, Anand, Gujarat, India. \\ "E-mail: istares2005@yahoo.com
}

Received: 16.07.2010, Accepted: 28.11.2011

\begin{abstract}
The study was conducted to estimate the biomass and net primary productivity of different age grouped (5, 10 and 15-year-old) Butea monosperma forest ecosystems in western India , Rajasthan (located between $23^{\circ} 49^{\prime}$ to $25^{\circ} 28^{\prime} \mathrm{N}$ latitudes and $73^{\circ} 0^{\prime}$ to $75^{\circ} 49^{\prime} \mathrm{E}$ longitudes) from June 2007 to May 2008. The vegetation biomass, forest floor biomass, tree litter fall and net primary productivity (NPP) of trees and shrubs were estimated and it was found that the tree biomass and net primary productivity increased with increasing age of the forest stand, whereas the herb biomass and net primary productivity decreased significantly $(\mathrm{P}<0.01)$ with increase in the forest age. The biomass of trees increased with age from $183.7 \pm 3.21$ to $298.3 \pm 3.57 \mathrm{t} \mathrm{ha}^{-1}$ while shrub biomass ranged from $4.9 \pm 1.61$ to $6.3 \pm 1.38 \mathrm{t} \mathrm{ha}^{-1}$ and the herb biomass fluctuated from $1.7 \pm 1.64$ to $2.1 \pm 1.81$. The tree layer NPP varied from 17.2 to $29.3 \mathrm{t} \mathrm{ha}^{-1}$ year $^{-1}$ whereas the NPP of the shrub layer was 0.88 to $1.6 \mathrm{tha}^{-1}$ year $^{-1}$. The productivity of the herb layer fluctuated from 2.3 to $3.1 \mathrm{t} \mathrm{ha}^{-1}$ year $^{-1}$. All values of biomass and NPP of trees, shrubs and herbs were low in 5-year-old, moderate in 10-year-old and high in 15-year-old forest stands. The total forest biomass increased from $190.7 \mathrm{t} \mathrm{ha}^{-1}$ in the 5-year-old to $306.3 \mathrm{t}$ $\mathrm{ha}^{-1} 15$-year-old forest and net primary productivity from $21.1 \mathrm{t} \mathrm{ha}^{-1}$ year $^{-1}$ in the 5 -yearold to $33.2 \mathrm{t} \mathrm{ha}^{-1}$ year $^{-1}$ in the 15 -year-old forest.
\end{abstract}

Key words: Butea monosperma, biomass, forest floor biomass, litter fall, net primary productivity.

\section{Introduction}

Butea monosperma Lam. is a small to medium-sized, tropical and sub tropical tree, 5 to 15 (max. 20) $\mathrm{m}$ tall, up to $45 \mathrm{~cm}$ dbh. $B$. monosperma is amongst the principal economic tree species commonly recommended for plantation programmes in dry tropical regions for soil and water conservation as well as for fuel wood and fodder production. Estimation of biomass and productivity are essential for determining the status and flux of biological materials in an ecosystem and for understanding the dynamics of the ecosystem (Anderson, 1970). However, the biomass and productivity of tree species varies from place to place due to variation in climate, soil, temperature and rainfall. Teller (1968) pointed out that forest floor biomass plays a significant role in the structure and functioning of forest ecosystems by acting as a nutrient reservoir and improves the infiltration rate and water 
holding capacity of soils. The quantity of tree biomass per unit area of land constitutes the primary data needed to understand the flow of materials and water through forest ecosystem (Swank and Schreuder, 1974). Lieth and Whittaker (1975) pointed out that if forest biomass is to be measured and analysed in its proper way as a part of production, this gives an overall picture of ecosystem functioning. According to Lodhiyal and Lodhiyal (1997), the rising demand of energy from renewable sources requires attention to woody biomass production system.

The increasing trends of plantations of an indigenous tree species are widely gaining popularity due to their higher biomass accumulation per unit area, better nutrient conservation efficiency and suitability in nutrient poor sites. Nirmal Kumar et al. (2009 a, b, c; 2010 a, b, c) have already carried out quantification and decomposition studies in dry tropical teak forests of Rajasthan. Some studies have been made over a long time regarding the biomass production of leguminous indigenous forest in India (Pacholi, 1997). But no such studies have been carried out in Butea plantations. Therefore, in the present study an attempt has been made to find out the biomass content and net primary productivity in three different aged Butea forest ecosystems Western India, Rajasthan. Moreover, various works have been carried out by Nirmal Kumar et al. (2009 a, b, c; 2010 a, b, c) in field of fuel wood properties, seasonal changes of bio elements and assessment of carbon stock in the Teak and Butea forest ecosystem, Western India, Rajasthan.

\section{Study Area}

The study was conducted in Butea plantation forest areas $\left(23^{\circ} 03^{\prime \prime} \mathrm{N}\right.$ latitude, $69^{\circ} 30^{\prime \prime} \mathrm{E}$, longitude; altitude $579.4 \mathrm{~m}$ above the mean sea level) from June 2007 to May 2008 at the Udaipur district in the state of Rajasthan which is $85 \mathrm{~km}$ away from the Udaipur city. The climate of the study area is semi-arid. There are three distinct seasons per year; winter (November to February), summer (April to mid June), and rainy season (mid-June to mid September). The climate is tropical with maximum temperature $45.3^{\circ} \mathrm{C}$ and minimum of $28.8^{\circ} \mathrm{C}$ during summers. Winters are little cold with the maximum temperature up to $26.8^{\circ} \mathrm{C}$ and the minimum dropping to $2.5^{\circ} \mathrm{C}$. Annual rainfall during the study period was $300 \mathrm{~mm}$ and the relative humidity ranged between 21 and $73 \%$. The soil is alluvial, reddish brown, to deep medium black and loamy with rocky beds. The plantation system, where the sampling was done, is composed of 5 to 15 years old Butea monosperma forest stands with a few individuals of Bambusa arundinacea, Lannea coromandelica, Wrightia tinctoria and Annona squamosa. The trees followed by shrubs like Jatropha curcas, Lantana camara and associated herbaceous vegetation mostly dominated by Cassia tora are also found in the study area. Grazing land under Butea forest was dominated by Cassia tora, followed by Achyranthes aspera, Blepharis maderaspatensis, Boerhavia diffusa and Cassia occidentalis. Butea forest was protected from grazing during the study period from June, 2007 to May, 2008. 


\section{Materials and methods \\ Estimation of biomass}

The total area planted with $B$. monosperma trees was 63 ha. Of this area, 5-, 10- and 15year old stand occupied 26,17 and 20 ha, respectively. The tree density in each Butea forest was 400 trees $\mathrm{ha}^{-1}$, respectively in 5-, 10 - and 15-years-old forest because of similar spacing (with plant to plant and row to row distances of $5 \mathrm{~m} \times 5 \mathrm{~m}$ in each way). A one hectare plot was sampled in each forest, which included four replicate subplots of $50 \mathrm{~m} \times 50 \mathrm{~m}(0.25 \mathrm{~h})$. To find out the accurate results, 100 trees in each sub-plot (400 trees in each forest) were measured. The height and diameter (dbh, $1.37 \mathrm{~m}$ ) of trees were measured by Ravi's multimeter and Tree calipers, respectively, in each forest.

For estimating density, the shrub and herb individuals were sampled in 50 quadrats of $2 \mathrm{~m} \times 2 \mathrm{~m}$ and $1 \mathrm{~m} \times 1 \mathrm{~m}$, respectively. To estimate the biomass of Butea forest, the selective harvest technique was adopted (Ovington, 1962; Lodhiyal and Lodhiyal, 1997). Two trees (B. monosperma) and two shrubs (J. curcas L.) of average dbh in each forest stand were harvested and separated into bole wood, bole bark, branches, twigs, leaves and reproductive parts, stump root, lateral roots and fine roots. The fresh weight of all components was determined in the field using a heavy weight spring balance or pan balance. Samples of approx. $500 \mathrm{~g}$ (fresh weight) of each tree component from each forest stand were taken separately to the laboratory and oven-dried at $60^{\circ} \mathrm{C}$ to a constant weight. Using the fresh/dry weight factor, the dry weight was estimated. Regression equations were developed for each tree components. The data were subjected to the regression in the form
$Y=a+b \mathrm{X}$, Where, $Y$ is the biomass of the component $(\mathrm{kg}), \mathrm{X}$ is the dbh. The mean diameter in each forest stand was used in the regression equation of the different components to obtain an estimate of mean biomass.

This value was then multiplied by tree density in each forest stand to obtain the total tree biomass. Like trees, regression equations were developed for finding the shrub biomass.

For herbaceous biomass, herbs were harvested at their peak season (rainy, September, 2009) from $10,50 \mathrm{~m} \times 50 \mathrm{~m}$ quadrates. The harvested material was divided into aboveground and belowground components fresh weight and dry weight was determined for each herb component. The total vegetation biomass was obtained by summing biomass values of trees, shrubs and herbs for each forest stand.

\section{Calculation of NPP}

After the selecting a permanent sample plot (area $1 \mathrm{ha}$ ) in each forest stand, 50 trees and shrubs in each sub-plot were marked with white paint at breast height in June, 2007 to assess diameter increments at annual intervals. The diameters of marked trees and shrubs were measured again in May, 2008. The mean diameter increments for each diameter class were then calculated. The net primary productivity of the different tree components (bole wood, bole bark, branches, twigs, leaves and reproductive parts stump root, lateral roots and fine roots), shrubs (roots, stem and leaves) and herbs was calculated for each forest stand following Rawat and Singh (1988) and Lodhiyal and Lodhiyal (1997). The sum of net production values of tree, shrub and herb layers yielded the total net primary production of the plantation site. 
J.I. Nirmal Kumar, P.R. Sajish, R.N. Kumar and K. Patel / Our Nature (2011) 9: 73-82

Data for forest floor litter were collected from ten, $50 \mathrm{~cm} \times 50 \mathrm{~cm}$ randomly placed quadrats once in each season, i.e., rainy, winter and summer. All the live and dead herbaceous shoots in each quadrat were first harvested at ground level. The litter on the forest floor was then collected carefully, avoiding contamination with soil as much as possible, and categorized into (a) fresh leaf litter, (b) partly decomposed litter, (c) wood litter and (d) miscellaneous litter (consisting of material other than the above). The collections were brought to the laboratory separately by category and ovendried weights were determined.

The litter input was measured by placing ten litter traps randomly on the forest floor in each site. Each trap was 50 $\mathrm{cm} \times 50 \mathrm{~cm}$ with $15 \mathrm{~cm}$ high wooden sides and fitted with a nylon net bottom. The litter was collected at monthly intervals during the study period, separated into leaf, wood, bark and reproductive parts. The samples were weighed after oven drying at $60^{\circ} \mathrm{C}$ to constant weight.

The biomass (above- and belowground) of herbs on all sites was determined during their peak growth in September, 2007. This value was assumed equal to net herb production. The sum of net production values of tree, shrub and herb layers yielded the total net primary production of the plantation site.

\section{Results and discussion Biomass}

The regression coefficients for all the above ground and belowground components of trees is given in table 1 . The selection of independent variable, dbh, was occasioned by the ease and accuracy in these measurements. It is evident from $r^{2}$-values, the relations of biomass with the dbh were

Table 1. Relationship between the biomass of tree components ( $\mathrm{Y} \mathrm{kg} /$ tree) and diameter at breast height $(\mathrm{X} \mathrm{cm})$ for Butea forests.

\begin{tabular}{|c|c|c|c|c|}
\hline \multirow{2}{*}{ Components } & \multicolumn{4}{|c|}{ Age of Butea forest stands (years) } \\
\hline & & 5 & 10 & 15 \\
\hline \multirow[t]{3}{*}{ Bole wood } & $\bar{a}$ & -0.0563 & -0.2284 & -3.2148 \\
\hline & $\mathrm{b}$ & 0.9354 & 1.5442 & 2.3544 \\
\hline & $\mathrm{r}^{2}$ & 0.994 & 0.983 & 0.985 \\
\hline \multirow[t]{3}{*}{ Bole bark } & $a$ & -3.2456 & -4.2542 & -5.2141 \\
\hline & b & 0.2432 & 0.4127 & 0.6314 \\
\hline & $r^{2}$ & 0.995 & 0.994 & 0.976 \\
\hline \multirow[t]{3}{*}{ Branch $^{\dagger}$} & $a$ & -1.5733 & -1.8955 & -2.4985 \\
\hline & b & 0.4605 & 0.5983 & 0.7256 \\
\hline & $r^{2}$ & 0.993 & 0.986 & 0.989 \\
\hline \multirow[t]{3}{*}{ Twigt } & $a$ & -2.0961 & -4.5143 & -5.3565 \\
\hline & $\mathrm{b}$ & 0.1069 & 0.2347 & 0.3754 \\
\hline & $r^{2}$ & 0.995 & 0.995 & 0.979 \\
\hline \multirow[t]{3}{*}{$\overline{\text { Leaf }}$} & $a$ & -2.1761 & -2.8647 & -3.2548 \\
\hline & b & 0.3133 & 0.3984 & 0.3766 \\
\hline & $r^{2}$ & 0.995 & 0.994 & 0.968 \\
\hline \multirow[t]{3}{*}{ Reproductive parts ${ }^{\S}$} & $a$ & -0.1258 & -1.6472 & -2.6542 \\
\hline & $\mathrm{b}$ & 0.0562 & 0.0697 & 0.1842 \\
\hline & $\mathrm{r}^{2}$ & 0.994 & 0.995 & 0.985 \\
\hline \multirow[t]{3}{*}{ Stump root ${ }^{\pi}$} & $a$ & -0.2543 & -1.6214 & -1.0355 \\
\hline & b & 0.5354 & 0.7354 & 0.9875 \\
\hline & $\mathrm{r}^{2}$ & 0.995 & 0.996 & 0.986 \\
\hline \multirow[t]{3}{*}{ Lateral roots } & $a$ & -0.2291 & -2.3561 & -2.0457 \\
\hline & $\mathrm{b}$ & 0.1684 & 0.3197 & 0.4021 \\
\hline & $\mathrm{r}^{2}$ & 0.994 & 0.994 & 0.944 \\
\hline \multirow{3}{*}{ Fine roots $^{* *}$} & $a$ & -2.5487 & -2.9854 & -4.2549 \\
\hline & b & 0.0681 & 0.1436 & 0.1649 \\
\hline & $r^{2}$ & 0.994 & 0.994 & 0.947 \\
\hline
\end{tabular}

All equations were significant at $\mathrm{P}<0.01, \dagger=$ shoots of larger dimension without leaves, $\$=$ current shoots bearing leaves, $\S=$ includes flowers and fruits, $\boldsymbol{\emptyset}=$ main root bearing $30 \mathrm{~cm}$ above- ground stem part, $\|=$ lateral branches of stump root (main root) with a diameter $>5 \mathrm{~mm}, * *=$ roots originate from lateral roots with a diameter $<5 \mathrm{~mm}$ and associated mycorrhizae.

found to be quite satisfactory. The calculation of biomass through $X^{2} h$ method ( $h$ being height) has not been used because the $r^{2}$ values from such equations did not indicate much improvement over those obtained with dbh (X). Therefore the regression model $Y=a+b \mathrm{X}$ was used for forest biomass computations. The biomass 
of each component and of the total tree was significantly related to the dbh.

Total biomass of trees increased with age from $183.7 \pm 3.21$ in 5-year- old stand to $298.3 \pm 3.57 \mathrm{t} \mathrm{ha}^{-1}$ in 15-year-old stand, of which above- and below-ground parts represented percent values of 83-87 and 1317, respectively (Tab. 2). Shrub biomass ranged from $4.9 \pm 1.61$ in 5 -year-old stands to $6.3 \pm 1.38 \mathrm{t} \mathrm{ha}^{-1}$ in 15-year-old stand, of which stem, foliage and roots accounted for about 53-62, 13-15 and 25-31\%, respectively. The herb biomass ranged from $1.7 \pm 1.64$ in 15 -year-old stand to $2.1 \pm 1.81$ in 5 -year-old stands. Of this, the above ground component accounted for $73-79 \%$. Herb biomass decreased with increasing age of the forest stand (Tab. 2). This could have been probably due to decrease in light penetration because of increase in forest canopy.

The total vegetation biomass ranged from $190.7 \pm 2.21 \quad$ (5-year-old stand) to $306.3 \pm 2.19 \mathrm{t} \mathrm{ha}^{-1}$ (15-year-old stand). The moderate amount of biomass was observed in 10-year-old stands. Of this, the tree layer accounted for 96 to $98 \%$, shrubs for $2-3 \%$ and herbs for $0.5-1 \%$ (Tab. 2). The present values fall with in the range reported for Eucalyptus stands (54-319 t ha ${ }^{-1}$; Attiwill, 1979), 100 plus year old oak forest (263$301 \mathrm{t} \mathrm{ha}^{-1}$; Negi et al., 1983), Eucalyptus plantation (319 t ha ${ }^{-1}$; Frederick et al., 1985 $a, b)$.

Analysis of variance showed significant $(\mathrm{P}<0.01)$ variations in total tree biomass and its components among plantations of different ages. The contribution of bole wood, branches, twigs, reproductive parts, lateral roots and fine roots increased with age while that of the remaining parts (herb layer) decreased (Tab. 2 ). The contribution of root biomass to the
Table 2. Biomass of different components $\left(\mathrm{t} \mathrm{ha}^{-1}\right)$ in tree, shrub and herb layers at different ages of Butea forests in Udaipur, Rajasthan.

\begin{tabular}{|c|c|c|c|}
\hline \multirow[t]{2}{*}{ Components } & \multicolumn{3}{|c|}{$\begin{array}{c}\text { Age of Butea forest stands } \\
\text { (years) }\end{array}$} \\
\hline & 5 & 10 & 15 \\
\hline Tree layer & $\begin{array}{c}183.7 \pm \\
3.21\end{array}$ & $\begin{array}{c}246.1 \pm \\
3.38\end{array}$ & $\begin{array}{c}298.3 \pm \\
3.57\end{array}$ \\
\hline $\begin{array}{l}\% \text { of allocation in } \\
\text { bole }\end{array}$ & 63.6 & 67.3 & 67.8 \\
\hline branch $^{\dagger}$ & 12.3 & 11.9 & 12.8 \\
\hline leaf & 6.5 & 5.1 & 4.3 \\
\hline reproductive parts & 0.7 & 1.3 & 1.9 \\
\hline coarse roots & 15.5 & 13.1 & 11.6 \\
\hline fine roots & 1.4 & 1.3 & 1.6 \\
\hline $\begin{array}{l}\text { Shrub layer } \\
\% \text { of allocation in }\end{array}$ & $4.9 \pm 1.61$ & $5.5 \pm 1.57$ & $6.3 \pm 1.38$ \\
\hline $\begin{array}{ll}\text { above } & \text { ground } \\
\text { parts }^{\S} & \end{array}$ & 69.4 & 75.2 & 71.8 \\
\hline $\begin{array}{l}\text { below ground } \\
\text { parts }\end{array}$ & 30.6 & 24.8 & 28.2 \\
\hline $\begin{array}{l}\text { Herb layer } \\
\% \text { of allocation in }\end{array}$ & $2.1 \pm 1.81$ & $1.9 \pm 1.79$ & $1.7 \pm 1.64$ \\
\hline $\begin{array}{l}\text { above ground } \\
\text { parts }\end{array}$ & 78.6 & 76.5 & 73.1 \\
\hline $\begin{array}{l}\text { below ground } \\
\text { parts }\end{array}$ & 21.4 & 23.5 & 26.9 \\
\hline Total vegetation & $\begin{array}{c}190.7 \pm \\
2.21\end{array}$ & $\begin{array}{c}253.5 \pm \\
2.24\end{array}$ & $\begin{array}{c}306.3 \pm \\
2.19 \\
\end{array}$ \\
\hline
\end{tabular}

$*=$ bole wood + bole bark, which accounted for 10.0$10.2 \%$ of the values; $\dagger=$ branch + twig, which accounted for $3.7-4.8 \%$ of the values; $\$=$ stump root (main root) + lateral roots (lateral branches of main root), which accounted for 3.8-4.2 \% of the values; $\S$ $=$ stem + foliage, which accounted for $13.1-16.1 \%$ of the values.

total biomass generally decreased with age (Lodhiyal and Lodhiyal, 1997).

According to Harris et al. (1980), although the importance of roots as structural, storage and physiologically active organs has been known, they have been neglected in most of the 'ecosystem studies' today because of difficulties surrounding investigation. For example, the root parts left in the soil of a mature Douglas fir accounted for only $11-18 \%$ of the weight of the total root system 
(Santantonio et al., 1977).

\section{Forest floor biomass}

The quantity of forest floor depends on canopy closure and climate. The biomass of litter on the forest floor increased with age of the forest stand. The seasonal mean total forest floor biomass (including herbaceous litter) increased from $4.04 \mathrm{t} \mathrm{ha}^{-1}$ in 5 -yearold to $5.1 \mathrm{ha}^{-1}$ in the 15 -year-old stands (Tab. 3). The herbaceous biomass, both live and dead, however, showed a reverse trend. The same trend and the range was observed for Populus deltoides plantations (4.6-6.1) (Lodhiyal et al., 1995) and Eucalyptus hybrid plantations (4.0-6.7 $\mathrm{t} \mathrm{ha}^{-1}$ ) (Bargali et al., 1992). Frederick et al. (1985 b) studied an age series of Eucalyptus regnans and stated that the native wood species and ferns generally increased with stand age, while herbaceous species declined.

The accumulated forest floor in the present study (Tab. 3) was lower than those reported for Pinus stands (13-110 $\mathrm{t} \mathrm{ha}^{-1}$; Ovington, 1965), oak forests (9.6-12.6 tha 1; Monk et al., 1970; Reiners and Reiners, 1970), Eucalyptus saligna (12.4 $\mathrm{t} \mathrm{ha}{ }^{-1}$; Richards and Charley, 1977), Eucalyptus obliqua (18.3 t ha ${ }^{-1}$; Attiwill et al., 1978), Eucalyptus regnans (47.5 $\mathrm{t} \mathrm{ha}{ }^{-1}$; Feller, 1980) and Pinus roxburghii forests (9.6$13.6 \mathrm{t} \mathrm{ha}^{-1}$; Chaturvedi and Singh, 1987 a) but is within the range reported for increment of trees. By using the same Vernier Calipers at exactly the same location on the tree, systematic errors in successive measurements of dbh of marked trees were reduced in the present work.

Total NPP ( $\mathrm{t} \mathrm{ha}{ }^{-1}$ year $\left.{ }^{-1}\right)$ of Butea forests at different ages is given in table 5 . NPP in the tree layer ranged from 17.2 (5year-old stand) to $29.3 \mathrm{t} \mathrm{ha}^{-1}$ year $^{-1}$ (15-yearold stand). Above-ground parts account for eucalyptus plantations (Bradstock, 1981; Frederick et al., 1985 b) and close to the values reported for Eucalyptus hybrid plantations (4.0-6.7 t ha ${ }^{-1}$; Bargali et al., 1992) and oak forest (Rawat and Singh, 1988). The smaller biomass on the forest floor indicates a high rate of decomposition under the warm and humid conditions.

\section{Litter fall}

Seasonal fluctuations like climatic variables, latitude, exposure, altitude, soil moisture and wind velocity etc., affect variation in litter fall (Chaturvedi and Singh, 1987a). Leaves are a major component of the total litter input. Total litter fall ranged from 2.97 in 5-year-old-stand to $4.61 \mathrm{t} \mathrm{ha}^{-1}$ year $^{-1}$ in 15-year-old stand (Tab. 4). Of this, leaf litter accounted for $71-80 \%$, with in the range reported for natural sal forests of Central Himalaya (60-80\%; Singh and Singh, 1992) and for temperate forest (40$84 \%$; Rodin and Bazilevick, 1967). However, wood litter represented 4-9\%, which is lower than the value reported for various forests around the world (10-36\%; Bray and Gorham, 1964; Killingbeck and Wali, 1978; Singh and Singh, 1992).

\section{Net Primary Productivity (NPP)}

The reliability of estimates of production for a site depends mainly on the accuracy in determinations of the annual biomass

78 (5-year-old stand) to 79\% (15-year-old stand) and below-ground parts for 20 (10year-old stand) to $22 \%$ (15-year-old stand). The NPP of the shrub layer was 0.88 (5year-old stand) to $1.6 \mathrm{t} \mathrm{ha}^{-1}$ year $^{-1}$ (15-yearold stand). Of this, above-ground and below-ground parts accounted for $70-71 \%$ and $30-31 \%$, respectively. The productivity of the herb layer was 2.3 (15-year-old stand) to $3.1 \mathrm{t} \mathrm{ha}^{-1}$ year $^{-1}$ (5-year-old stand). 
J.I. Nirmal Kumar, P.R. Sajish, R.N. Kumar and K. Patel / Our Nature (2011) 9: 73-82

Table 3. The average forest floor biomass ( $\mathrm{t} \mathrm{ha}^{-1}$, across seasons) and turnover of litter (rate and time) in Butea forests of Udaipur, Rajasthan.

\begin{tabular}{|c|c|c|c|}
\hline \multirow{2}{*}{ Components } & \multicolumn{3}{|c|}{ Age of Butea forest stands (years) } \\
\hline & 5 & 10 & 15 \\
\hline Forest floor biomass $\left(\mathrm{t} \mathrm{ha}^{-1}\right)$ & $4.04 \pm 2.11$ & $4.92 \pm 2.36$ & $5.1 \pm 3.02$ \\
\hline$\%$ Allocation in & & & \\
\hline Fresh leaf litter & 9.1 & 9.6 & 10.1 \\
\hline Partially and more decomposed litter & 24.6 & 28.4 & 32.3 \\
\hline Wood litter & 5.3 & 11.9 & 18.5 \\
\hline Miscellaneous litter ${ }^{*}$ & 24.4 & 20.1 & 18.8 \\
\hline$\underline{\text { Herbaceous litter }}^{\dagger}$ & 36.6 & 30.0 & 20.3 \\
\hline Turnover rate (kg year) & 0.94 & 0.93 & 0.92 \\
\hline Turnover time (t, year) & 1.06 & 1.08 & 1.09 \\
\hline
\end{tabular}

$*=$ includes reproductive parts of trees and litter parts of shrubs, $\dagger=$ includes living and dead herbaceous material.

Table 4. Litter production ( $\mathrm{t} \mathrm{ha}^{-1} \mathrm{year}^{-1}$ ) in Butea forests of Udaipur, Rajasthan.

\begin{tabular}{lccc}
\hline \multirow{2}{*}{ Litter components } & \multicolumn{3}{c}{ Age of Butea forest stands (years) } \\
\cline { 2 - 4 } & 5 & 10 & 15 \\
\hline Leaf litter $_{\text {Wood litter }}^{*}$ & $2.38(80.1)$ & $2.91(75.0)$ & $3.27(70.9)$ \\
Reproductive litter & $0.13(4.4)$ & $0.23(5.9)$ & $0.40(8.7)$ \\
Miscellaneous litter & $0.04(1.3)$ & $0.10(2.6)$ & $0.194 .1)$ \\
\hline Total & $0.42(14.2)$ & $0.64(16.5)$ & $0.75(16.3)$ \\
\hline
\end{tabular}

$*=$ includes barks, twigs and branches; $\uparrow=$ includes inflorescences, pods and fruits of trees and shrubs; $\stackrel{\dagger}{\dagger}=$ includes the leaf litter of shrubs and herbs.

Table 5. Component wise net primary productivity $\left(\mathrm{t} \mathrm{ha}^{-1}\right.$ year $\left.{ }^{-1}\right)$ in trees, shrubs and herbs of Butea forests of Udaipur, Rajasthan.

\begin{tabular}{lccc}
\hline \multirow{2}{*}{ Vegetation } & \multicolumn{3}{c}{ Age of Butea forest stands (years) } \\
\cline { 2 - 4 } & $\mathbf{5}$ & $\mathbf{1 0}$ & $\mathbf{1 5}$ \\
\hline Tree layer & $17.2 \pm 2.31$ & $23.8 \pm 2.66$ & $29.3 \pm 2.98$ \\
\% of allocation in & & & \\
bole & 58.4 & 58.9 & 57.1 \\
branch & 12.1 & 12.6 & 13.4 \\
leaf & 6.7 & 6.9 & 7.1 \\
reproductive parts & 1.2 & 1.4 & 1.7 \\
coarse roots & 15.9 & 13.5 & 13.3 \\
fine roots & 5.7 & 6.7 & 7.4 \\
\hline Shrub layer & $0.8 \pm 0.78$ & $1.4 \pm 0.89$ & $1.6 \pm 0.95$ \\
\% of allocation in & & & \\
above ground parts & 70.9 & 71.2 & 69.5 \\
below ground parts & 29.1 & 28.8 & 30.5 \\
\hline Herb layer & $3.1 \pm 1.53$ & $2.8 \pm 1.65$ & $2.3 \pm 1.82$ \\
\% of allocation in & & & \\
above ground parts & 78.2 & 76.1 & 72.7 \\
below ground parts & 21.8 & 23.9 & 27.3 \\
\hline Total vegetation & $21.1 \pm 1.54$ & $28.0 \pm 1.73$ & $33.2 \pm 1.92$ \\
\hline
\end{tabular}


J.I. Nirmal Kumar, P.R. Sajish, R.N. Kumar and K. Patel / Our Nature (2011) 9: 73-82

Table 6. Total net primary productivity (NPP) of Butea forests compared with other forests and plantations around the world.

\begin{tabular}{|c|c|c|c|}
\hline Vegetation & Location & $\begin{array}{c}\text { NPP } \\
\left(\text { t ha }^{-1} \text { year }^{-1}\right) \\
\end{array}$ & References \\
\hline$\overline{\text { Camelia japonica }}$ & Japan & 29.4 & Kan et al.(1965) \\
\hline Cryptomeria japonica & Japan & 10.9 & Tadaki et al. (1965) \\
\hline Pine forest & USA & 11.0 & Whittaker (1966) \\
\hline Tropical rain forest & Thailand & 28.6 & Kira et al. (1967) \\
\hline Conifer forest & USSR & $7.0-10.0$ & Rodin and Bazilevick (1967) \\
\hline Tropical rain forest & Java & 24.3 & Warner (1970) \\
\hline Tropical moist forest & - & 11.4 & Golley et al. (1975) \\
\hline Dry deciduous forest & India & $14.6-15.7$ & Singh (1979) \\
\hline Tropical rain forest & Malaysia & 19.2 & Bullock (1981) \\
\hline Shisham plantation ( 24 years old) & India & 7.2 & Sharma et al. (1988) \\
\hline Chir-pine forest & India & 17.3 & Rana et al. (1989) \\
\hline Eucalyptus plantation (8 years old) & India & 23.4 & Bargali et al.(1992) \\
\hline Low density poplar plantation & India & 24.5 & Lodhiyal et al.(1995) \\
\hline High density poplar plantations & India & 32.4 & Lodhiyal and Lodhiyal (1997) \\
\hline Dalbergia sissoo forest & Bihar (India) & 22.3 & Pacholi (1997) \\
\hline Tarai Shisham forests & Uttaranchal (India) & $12.6-20.3$ & Lodhiyal et al. (2002) \\
\hline Butea monosperma forests & Rajasthan (India) & $33.1-45.2$ & Present study \\
\hline
\end{tabular}

Above-ground parts accounted for 73 (15-year-old stand) to $78 \%$ (5-year-old stand) and below-ground parts for 22 (5year-old stand) to $27 \%$ (15-year-old stand).

The total NPP in vegetation ranged from 21.1 (5-year-old stand) to $33.2 \mathrm{t} \mathrm{ha}^{-1}$ year $^{-1}$ (15-year-old stand), of which the tree layer accounted for 88.2 (5-year-old stand) to $91.4 \%$ (15-year-old stand), the shrub layer for 2.4 (5-year-old stand) to $3.5 \%$ (15year-old stand) and the herb layer for 5.1 (15-year-old stand) to $9.4 \%$ (5-year-old stand) (Tab. 5). The NPP of 10-year-oldstands was found moderate between 5-year and 15-year-old stands.

Comparisons with other forests and plantations around the world show that the NPP of the present Butea forests (21-33 t ha $^{-1}$ year $^{-1}$ ) was much higher than the values reported for Shisham forests (13-20 $\mathrm{t} \mathrm{ha}^{-1}$ year $^{-1}$; Lodhiyal et al., 2002), for Gmelina arborea forest $\left(10 \mathrm{t} \mathrm{ha}^{-1}\right.$ year $^{-1}$; Pacholi, 1997) (Tab. 6). The difference in average net production among different forests may be partly caused by climate, especially the length of the growing season when both thermal and moisture conditions are favourable. The high productivity in the present study is probably caused by greater leaf surface and larger duration of photosynthetic activity (Lodhiyal and Lodhiyal, 1997).

\section{Acknowledgement}

Authors are grateful to Mr. J. Rao, Executive Director; Foundation for Ecological Security, Anand, Gujarat for financial assistance.

\section{References}

Anderson, F. 1970. Ecological studies in a Seaman Woodland and meadow area. Southern Sweden II. Plant biomass, primary production and turnover of organic matter. Bolaniska Notiser 123: 8-51.

Attiwill, P.M. 1979. Nutrient cycling in a Eucalyptus obliqua (L'Hent.) forest. III. Growth, biomass and net primary production. Australian Journal of Botany 27: 439-458. 
J.I. Nirmal Kumar, P.R. Sajish, R.N. Kumar and K. Patel / Our Nature (2011) 9: 73-82

Attiwill, P.M., H.B. Guthrie and R. Leuning 1978. Nutrient cycling in an Eucalyptus obliqua (L' Herit) forest. I. Litter production and nutrient return. Australian Journal of Botany 26: 76-91.

Bargali, S.S., S.P. Singh and R.P. Singh 1992. Structure and function of an age series of eucalypt plantations in Central Himalaya. I. Dry matter dynamics. Annals of Botany 69: 405-411.

Bradstock, R. 1981. Biomass in an age series of Eucalyptus grandis plantation. Australian Journal of Forest Research 11: 111-127.

Bray, J.R. and E. Gorham 1964. Litter production in the forests of the World. Advances in Ecological Research 2: 101-57.

Chaturvedi, O.P. and J.S. Singh 1987a. A quantitative study of the forest floor biomass, litter fall and nutrient return in a Pinus roxburghii forest in Kumaun Himalaya. Vegetatio 71: 97-106.

Feller, M.C. 1980. Biomass and nutrient distribution in two eucalypt forest ecosystems. Australian Journal of Ecology 5: 309-333.

Frederick, D.J., H.A.I. Madgwick, G.R. Olnerand and M.F. Jurgenson 1985b. Dry matter and nutrient content of 8-year-old Eucalyptus saligna growing of Tahoka forest. New Zealand Journal of Forestry Science 15: 251-254.

Frederick, D.J., H.A.I. Madgwick, M.F. Jurgenson and G.R. Oliver 1985a. Dry matter content and nutrient distribution in an age series of Eucalyptus regnans plantations in New Zealand. New Zealand Journal of Forestry Science 15: 158-179.

Harris, W.F., D. Santantonio and D. Mcginty 1980. The dynamic belowground ecosystem. In: Forests: Fresh perspectives from ecosystem analysis (Ed. R.H. Waring). Oregon State University Press, Corvallis, Oregon. pp. 119-130.

Killingbeck, K.T. and M.K. Wali 1978. Analysis of North Dakota Gallery forest: Nutrient trace element and productivity relations. Oikos 30: 2960.

Lieth, H. and R.L. Whittaker 1975. In: Primary productivity of Biosphere (Editor's preface). Springer, New York.

Lodhiyal, L.S. and N. Lodhiyal 1997. Variation in biomass and net primary productivity in short rotation high density Central Himalayan poplar plantations. Forest Ecology and Management 98: 167- 179.
Lodhiyal, L.S., R.P. Singh and S.P. Singh 1995. Structure and function of an age series of poplar plantations in Central Himalaya. I. Dry matter dynamics. Annals of Botany 76: 191-199.

Lodhiyal, N., L.S. Lodhiyal and Y.P.S. Pangtey 2002. Structure and function of Shisham forests in Central Himalaya, India: Dry matter dynamics. Annals of Botany 89: 41-54.

Monk, C.D., G.D. Child and S.A. Nicholson 1970. Biomass, litter and leaf surface area estimates of an Oak Hickory forest. Oikos 21: 138-141.

Negi, K.S., Y.S. Rawat and J.S. Singh 1983. Estimation of biomass and nutrient storage in a Himalayan moist temperate forest. Canadian Journal of Forest Research 13: 1185-1196.

Nirmal Kumar, J.I., R.N. Kumar, K. Patel and R.K. Bhoi 2009a. An assessment of carbon stock for various land use system in Aravally mountains, Western India. Mitig Adapt Strateg Glob Change: DOI 10.1007/s11027-010-9240-3.

Nirmal Kumar, J.I., R.N. Kumar, K. Patel and R.K. Bhoi 2009b. An assessment of Indian fuelwood with regards to properties and environmental impact. Asian Journal of Energy and Environment 10(2): 99-107.

Nirmal Kumar, J.I., R.N. Kumar, K. Patel and R.K. Bhoi 2010a. An evaluation of fuelwood properties of some Aravally mountain tree and shrub species of Western India. Biomass and Bioenergy: DOI:10.1016/j.biombioe.2010.08.051.

Nirmal Kumar, J.I., R.N. Kumar, P.R. Sajish and R.K. Bhoi 2010b. Wood and leaf litter decomposition and nutrient release from Tectona grandis Linn. $\mathrm{f}$. in a Tropical Dry Deciduous forest of Rajasthan, Western India. Journal of Forest Science 26(1): 17-23.

Nirmal Kumar, J.I., R.N. Kumar, R.K. Bhoi and K. Patel 2010c. Seasonal changes of bioelements in the litter and their potential return to green leaves in five species of the Indian tropical dry deciduous forest, Western India. Journal of Forestry Research 21(1): 33-38.

Nirmal Kumar, J.I., R.N. Kumar, R.K. Bhoi and P.R. Sajish 2009c. Quantification of nutrient content in above-ground biomass of teak plantation in tropical dry deciduous forest of Udaipur, Rajasthan, India. Journal of Forest Science 55(6): 251-256. 
J.I. Nirmal Kumar, P.R. Sajish, R.N. Kumar and K. Patel / Our Nature (2011) 9: 73-82

Ovington, J.D. 1962. Quantitative ecology and the woodland ecosystem concept. Advances in Ecological Research. Vol. 1. New York: Academic Press.

Ovington, J.D. 1965. Organic production, turnover and mineral cycling. Biological Review 40: 295336.

Pacholi, R.K. 1997. Biomass productivity and nutrient cycling in Cassia siamea, Dalbergia sissoo and Gmelina arborea plantations. Kumaun University, India. (Ph.D. Thesis).

Rawat, Y.S. and J.S. Singh 1988. Structure and function of oak forest in Central Himalaya: Dry matter dynamics. Annals of Botany 62: 397.

Reiners, W.A. and N.M. Reiners 1970. Energy and nutrient dynamics of forest floors in three Minnesota forests. Journal of Ecology 58: 497519.

Richards, B.N. and J.L. Charley 1977. Carbon and nitrogen flux through native forest floors. In:
Proceedings of Nutrient Cycling in Indigenous Forest Ecosystems Symposium. CSIRO Division Land Resources Management, Perth, Australia. pp. 65-82.

Rodin, L.E. and N.I. Bazilevich 1967. Production and mineral cycling in terrestrial vegetation. Oliver and Boyd, Edinburgh. 288p.

Santantonio, D., R.K. Hermann and W.S. Overton 1977. Root biomass studies in forest ecosystems. Pedobiologia 17: 1-31.

Singh, J.S. and S.P. Singh 1992. Forest of Himalaya, Structure, functioning and impact of man. Nainital, India: Gyanodaya Prakashan.

Swank, W.T. and H.T. Schreuder 1974. Camparisons of three methods of estimating surface area and biomass for a forest of young eastern white pine forest. Science 20: 91-100.

Teller, H.L. 1968. Impact of forest land use on floods. Unasylva 22: 18-20. 